\title{
The Analysis Of Musyarakah Contract Sharing System Implementationin BPRS Saka Dana Mulia Kudus
}

\author{
Nur Huda', Fitri Fajri ${ }^{2}$ \\ 1,2Universitas Islam Negeri Walisongo Semarang, Indonesia \\ nurhuda@walisongo.ac.id
}

\begin{abstract}
Purpose - This research aims to know how the implementation of revenue sharing system to Musyarakah finance and to know the Conformity between the implementation done with Fatwa DSN No.08/DSNMUI/IV/2000.
\end{abstract}

Method - The study uses a qualitative descriptive approach with a type of case study research.

Result- The results showed that a). the implementation of revenue sharing system to Musyarakah finance in BPRS Saka Dana Mulia uses projections or estimates between 1,75\% - 2,5\% multiplied by the bank's capital. This revenue sharing system has been determined at the beginning of the nominal magnitude of the result for which the customer must be deposited every month. But the bank continues to see the customer's business, when the customer's business suffered losses that are not caused by human error then the bank and the customer will renrenegotiate regarding the outcome.b). The implementation of Musyarakah finance to PT. BPRS Saka Dana Mulia which has been adjusted to Fatwa DSN No.08/DSNMUI/IV/2000 located at the statement of ijab qabul, contract object (capital, work, andloss), Operational costs and disputes. While that is still not appropriate, that is in the part of the object contract about the profit.

Implication - This research is only researching in PT. BPRS Saka Dana Mulia Kudus.

Originality - there are differences in the division of sharing system between theories and practices implemented in BPRS Saka Dana Mulia.

Keywords: Musyarakah Finance; Sharing System; Estimation. 
Nur Huda, Fitri Fajri

\section{Introduction}

Musyarakah Contract is a form of financing based on the sharing system. As set forth in the provisions Fatwa DSN No.08/DSN-MUI/IV/2000 about finance of Musyarakah, where the point from Fatwa DSN is stated AL-ARBAH | 96 thatcommunity needs to improve welfare and effort sometimes require funds from other parties, among others through financingMusyarakah, which is financing is based on the contract of cooperation between two or more parties for a particular business where each party contributes funds with the provision that the profit and risk will be borne together in accordance with the agreement.

In Fatwa DSN No.08/DSN-MUI/IV/2000 That stipulates some provisions such as the contract object in which the third point is about the profit that stipulates that "each partner's profits must be shared proportionally on the basis of the entire profit and no amount specified in Set for a partner ". One of the characteristics or conditions of Musyarakah is that the amount of revenue share for the partners is determined based on the ratio agreed from the revenues gained during the contract period not from the amount of investment transmitted.

Bank Pembiayaan Rakyat Syari'ah (BPRS) Saka Dana Mulia located in Jl. Jendral Sudirman Dersalam Bae Kudus is a bank that conducts business activities based on the principle of sharia that in its activities does not provide services in the payment traffic. One of the product from BPRS Saka Dana Mulia in fund distribution is short-term financing usingMusyarakahcontract,

In this case researchers have observed the procedure of short-term financing products using Musyarakah contract where (sharing system) implemented in BPRS Saka Dana Mulia is estimated 2,5\% multiplied by the capital which is realized by the bankAccording to Mr. Mukhlis as director of operations said that "the establishment of a Musyarakah contract of $2.5 \%$ is in the middle or BEP (Break Event Point) which is not very incriminated by the customer and does not harm the Bank". 
From the background description above, there is a difference in the division of the ratio of the outcome between theory and practice applied in BPRS Saka Dana Mulia. Where based on the theory that ratio sharing system to Musyarakah contract is set from the portion of the ratio multiplied by the profit, the outcome of the business or income. While those applied in BPRS Saka Dana Mulia is the devision of shaing systemset in 2,5\% from the capital distributed not from the profit or revenue of the customer's business.

\section{Literature Review}

Some studies on the outcomes of Musyarakah system have been conducted by a number of researchers. Muhammad Aswad (2014) For example, is the study about Financing outcomes analysis in Sharia banking. The results showed that the implementation of the scheme for the outcome as a benchmark return in the economy. The division of the ratio set at the beginning of the transaction is fixed but the nominal value has not been known for sure but see the profit or loss that will occur later. In determining ratio ratios known as 1) Revenue sharing System; 2) Groos Profit System; and 3) Profit Sharing System. But it is often used in Sharia bank, Revenue sharing System because the model is simple and easy for fund owners and fund managers.

Other research conducted by Mahmudatus Sa'diyah and Nur Aziroh (2014) which is talking aboutMusyarakah infiqih and syariah banking. The results showed that Musyarakah applied in Sharia banking there are some things that are still the same as conventional Bank that is in the ratio for the results set in the beginning and the nominal money that must be deposited to the bank Set at the beginning, the risk of business from contract of financing is not the responsibility of both parties, so that the customer becomes the party to be harmed. As well as the guarantee, and management that is practiced by sharia banking that is not in accordance with the jurisprudence perspective that is seen with the enactment of collateral or collateral that becomes an absolute condition for financing the customer. The second difference of research with this research is from the selection of research objects, namely 
Nur Huda, Fitri Fajri

BPRS Saka Dana Mulia Kudus And more focused on the calculation process and the negotiation of outcomes in Musyarakah contract applied there. Thus, the results of this research are expected to increase knowledge about the implementation of the system for the outcome of Musyarakah on both theory and practice.

Musyarakah derived from the Arabic language syirkah which means mixing. In this case mixing one capital with another capital so that it can not be separated and should not be distinguished by one part with other parts. According to the meaning of Syara, Syirkah is a contract between two or more parties who agree to do work for the purpose of obtaining profit

Musyarakah contract is an investment transaction of two or more owners of funds and/or goods to secure certain business in accordance with sharia by the distribution of business outcomes between the two parties based on the agreed ratio, while the division of losses based on the proportion of capital respectively.

In Musyarakah financing transaction flow above, it is explained that the customer filed Musyarakah to Syariah Bank financing, and then the bank performs an evaluation of the eligibility to apply using the analysis 5C (character, Capacity, Capital, Commitment, callacteral) followed by verification. If the customer is deemed worthy, there will be a contract signing of Musyarakah. Then the bank and the client alike-the same as providing capital for business implementation, and the customer as active partner began to manage the business. After obtaining the business results, then the profit is divided according to the ratio and loss without omission divided according to the portion of capital. Furthermore, the bank receives a return of capital and the result, if the customer has returned all bank's capital, then the next business becomes the customer's wholly.

Sharing system calculation mechanism can be done with two kinds of approaches, namely 1) Profit sharing, in the economic dictionary profit can be interpreted as profit. But in terms of profit is the difference arising from the total revenue (total revenue) a company is greater than the total cost. In 
Sharia banking profit sharing often uses the term profit and loss sharing, where the division between the profit and loss of revenues received on the results of the effort obtained. The system of profit and loss sharing in the implementation is a form of a cooperation agreement between the financier (investor) and the capital Manager (Enterpreneur) in conducting economic business activities, where between the two will be bound to contract that in In such efforts if the profit will be divided both parties according to the agreement ratio at the beginning of the agreement, the profit to be shared is the entire income after deducting the operational costs during the business process. And if the loss of business will be borne together according to the portion. 2) Revenue Sharing, Revenue sharing comes from two syllables that come from the English language. Revenue means earnings, outcomes or revenues. While sharing is a verb form of share that means for. Thus the revenue sharing language is the share of results, earnings, and revenue. In Economic dictionary revenue is the result of money received by a company from the sale of goods and services. In the principle of economic revenue can be interpreted as the total acceptance of the business results in production activities. Revenue covers the total cost of sales (capital) plus the profit from the yield (profit). In Sharia banking, revenue is the result received by the bank from the distribution of funds (investments) into the form of productive assets, namely the placement of bank funds on the other party. This is a difference or a number of more than productive assets with the result of bank acceptance.

\section{Methods}

The study uses a qualitative descriptive approach to the type of case study research. The research location for obtaining research data is PT. Bank Pembiayaan Rakyat Syariah (BPRS) Saka Dana Mulia. Located in Jl. Jendral Sudirman 857- 858 Dersalam Bae Kudus. The data used comes from primary and secondary data. The primary Data is obtained directly by interviewing operations director, Mr. Muklis Arifiyanto, The financing Admin is Ani Khoirunnisa' and customer Musyarakah. Secondary data is derived from the documentation study by learning data from the BPRS Saka Dana 
Nur Huda, Fitri Fajri

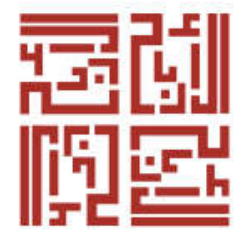

AL-ARBAH | 100

Mulia, book, Fatwa DSN, andbrochure. Data analysis is done by describing the meaning of data or the phenomenon that the author can capture, by showing its evidence. This technique is used to describe the data researchers gather both from interviews, observations and documentation during research in BPRS Saka Dana Mulia.

\section{Results and Discussion}

Short-term financing is a product owned by PT.BPRS Saka Dana Mulia who use t Musyarakah financing contract is intended for customers who have agricultural businesses, plantations, farms, fisheries and contractors who require fast and seasonal capital. The term of this product is the first, maximum 6 months with the realization of disbursement of financing less than Rp. 100.000.000 Which are usually used for agriculture, plantation, fisheries and animal husbandry. The second, 1 year with the realization of disbursement more than Rp. 100.000.000 this is usually for a contractor.

Simply the implementation of Musyarakah financing in BPRS Saka Dana Mulia That is the bank and the customer are partnering or cooperation where the two are the same - giving capital to run a business. The portion of capital here is not always the same between the Bank and the customer, the Bank's portion of capital depends on how much capital the customer has already owned to conduct his business. So the bank just added its capital shortage only. The portion of the capital contributed will affect the share of the result later.

Sharing system implemented in BPRS Saka Dana Mulia uses sharing system and Projection or estimation. Although it is already using the ratio, but the often used are estimates. Match to the interview with Mr Muklisasthe director of operations said that "the implementation of our BPRS immediately gave estimates. But if the customer is right - really looking for the ratio, we can navigate there. It does in principle use the ratio, but we take the rate alone, using the estimate. "So this estimate as a way to facilitate the customer who can not calculate the results of his business. The estimate used is between $1.75 \%-2.5 \%$ multiplied by the amount of capital realized by the 
bank. Mr. Muklis said that "The estimate is made as semoderat as possible not too high and not too low. This estimate does not fix (fixed) so that it can change depending on the results in which it is represented and the approval of the customer."

The estimated system is enforced since its inception BPRS Saka Dana Mulia made by the President Director. The estimation is dynamic, so initially set an estimate of $2.5 \%$, then because the competition in the market more and more, the bank changed the estimate from the initial $2.5 \%$ to below $2.5 \%$ ie between 1.75\%-2.5\%. Installment in Musyarakah financing is that customers are obliged to deposit for the result every month, while the principal is deposited in maturity. But if a customer in a 6-month contract within 2 months can nod the outcome and part of the financing, the result of the 3rd month will be $2.5 \%$ of the remaining principal.

Based on an interview with Mr. Abdul who has about 4 years become a customer in BPRS Saka Dana Mulia dengan Using Musyarakah Financing for the type of agriculture said that "I don't mind with the estimation, because it has become my obligation to give the result of the capital that has been given by the bank. But if it can be somewhat lowered for the outcome. I am a sugarcane business, but besides sugarcane also plant others such as palawija, cassava and others make a close alone because of our sugarcane GA efforts May 1 month once harvest, incidentally I have a kos-kosan too, so to share the results every month Yes From the outcome of the cost of the kosan and planting the crops ". When the customer and the bank have agreed until the end of the contract time using the estimate, Yasudah that fix. But if it turns out that there is a decline in results caused by natural factors, it will be negotiated again for the average outcome at the end of time. So the negotiations were done behind not in front. And the negotiation happens when there are things that do need to be talked about, if not to be talked about, yasudah that means the customer agrees to the end using the estimate.

Mr. Muklis said that "if the business is executed in fact there is a decline in production or results, and not from the mistake of intentional or not human error then the bank will accept it and change the outcome". As said by Mr. 
Nur Huda, Fitri Fajri

Abdul as the customer added that "it is true that the bank when I suffer from the production, I and the bank are negotiating back for the outcome at the end of the month, but usually the negotiation process for the return is done by Long time customers who are really already on their way to business and happen to decline. That time I was lowered from $2.5 \%$ to $2 \%$ ".

Here is a sample calculation for the results applied by PT.BPRS Saka Dana Mulia, for example short-term financing for agriculture requires: The capital for the farm is Rp. 20.000.000, Bank Capital's Portion Rp. 10.000.000: 50\%, Customer's capital portion Rp. 10.000.000: 50\%

From the capital given by the bank Rp. 10.000 .000 It can usually make how much profit, for example is making profit for about Rp. 1.000.000. Then the calculation is as follows: Sharing system calculation, If the ratio of the Bank's sharing system is determined by the percentage multiplied by the result of the business, the Bank will be for example the sharing system between Bank and the customer is $30 \%: 70 \%$. Therefore the Bank is :Rp. $1.000 .000 \times 30 \%=$ Rp. 300.000 , sharing system is Rp. 300.000 and will be deposited to the bank. Estimation calculation, With sharing system estimation 2,5\% for the Bank, so Bank profit is Bank Capital x Estimation: Rp. $10.000 .000 \times 2,5 \%=$ Rp. 250.000 , So the sharing system that has to be deposited monthly by the customer is Rp. 250.000

According to the two calculations for the above result can be concluded that the share of results applied in BPRS Saka Dana Mulia is estimation multiplied by bank capital is smaller than the sharing system that must be implemented is multiplied by the outcome of the effort. According to Mr. Muklis Arifiyanto, "Should use the appropriate one multiplied by the outcome of the effort but the bank chooses to apply a more simple and when the blackened collapse will be equal even lower than should be applied in Musyarakah contract"

The goal with an estimate of between $1.75 \%-2.5 \%$ multiplied by the amount of capital realized by the bank is to facilitate the customer to provide 
the share for the bank as well as the parameters of the bank and the customer to later customers can responsible for the management of its funds.

Table 1. Results of total estimated data sharing system

\begin{tabular}{cc}
\hline Percentage & Total \\
\hline $2.50 \%$ & 21 \\
$2.00 \%$ & 15 \\
$1.80 \%$ & 4 \\
TOTAL & 40 \\
\hline
\end{tabular}

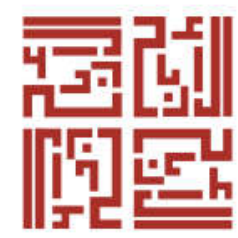

From the data can be seen that 40 customers Musyarakah get the projection/estimation of different outcomes, namely there are 21 customers who get an estimation of 2.50\%, 15 customers get an estimate of $2.00 \%$, and 4 customers get an estimation of $1.80 \%$. The difference between these estimates is influenced by some, including the following 1) Business eligibility, business eligibility is one of the considerations in setting estimates. Business feasibility here means that the business is doing well, can provide good results or profit. For example, if the customer's business deserves to be given a capital, but see from previous earnings, the business has not too much income which means that the customer's ability to provide revenue share to the bank will not be Many. This will affect the estimated magnitude of the customer. If the customer's business usually gets a big profit then the estimate will be high $2.5 \%$ but if the customer's business usually gets a small profit then the low estimate can be below 2.5\%. 2) The reality of field competition, the reality of field competition affects the determination of estimates given to customers. Competition in the field means competition between BPRS Saka Dana Mulia with other financial institutions, which can provide a percentage of estimates for smaller outcomes. An example of a customer filed for financing at BPRS Saka Dana Mulia by wanting an estimate for the result $2 \%$. Because financial institution $\mathrm{X}$ also gives an estimate of $2 \%$, so BPRS Saka Dana Mulia will approve the customer's wishes from the customer to choose another institution. 3) Analysis of SLIK and 5C, the Financial Information Services System (SLIK) and 5C analysis will affect the 
Nur Huda, Fitri Fajri

determination of the bank's estimation. So the Bank will analyze the SLIK and $5 \mathrm{C}$ before setting the estimated magnitude. If the bank is analyzing the SLIK and $5 \mathrm{C}$ of a customer, and the result is good then the bank will set an estimate of $2.5 \%$ and if the result is sufficient or moderate then it will set the estimate below $2.5 \%$.

The application for the sharing system applied in BPRS Saka Dana Mulia Indeed use estimation, which is clearly defined the nominal magnitude of projection for the outcome in Musyarakah contract. This estimate is derived from the calculation, which is obtained on the basis of an agreement between the customer and the bank in the form of percentages influenced by the results of the previous customer's efforts. Once determined, the bank determines its estimate. Although there are already calculations but the average is used to calculate for the results with the estimate because it is easier and more simple for banks and customers. In the share of the results do use estimation, but the bank will still see the results of the customer's business, whether the loss or not, if suffered losses caused by natural factors and not because human error then the customer and the bank will be Renegotiate for the outcome. This is a good action that should be applied by sharia banks, so the bank still sees the results of the customer's business in what it looks like.

\section{Conclusion}

The application of Musyarakah contract sharing system in BPRS Saka Dana Mulia Using projections or estimates between 1.75\%-2.5\% multiplied by the bank's capital. The system for this outcome has been determined at the beginning of the nominal agreement for the result that must be deposited by the customer every month. But the bank still sees the customer's business, when the customer's business suffered losses that are not caused by human error then the bank and the customer will be negotiated again about the outcome.

The application of musyarakah in PT. BPRS Saka Dana Mulia In accordance with Fatwa DSN No. 08/DSN-MUI/IV/2000 located in the 
statement of Ijab Qabul, object of agreement (capital, work, and loss), operational costs and disputes. While that is still not appropriate, that is in the part of the object Contract about the profit. Where the profit for the outcome should be distributed to the Bank and the customer based on the total profit or real income of the customer effort multiplied by the share of the outcome in the form of percentages set at the beginning of the contract.

It is better to use the calculation of the outcome in the form of percentages for customers who can calculate their own business results. It is hope that PT. BPRS Saka Dana Mulia In implementing Musyarakah financing to be true in regard to the general provisions based on sharia principles, especially in Fatwa DSN No.08/DSN-MUI/IV/2000 about Musyarakah finance.

\section{References}

Al Hafidh Ibnu Hajar Al Asqalani. (2011). Bulughul Maram. Surabaya: Grafis Mutiara.

Aswad Muhammad. Analisis Bagi Hasil Financing Dalam Perbankan Syariah. (jurnal AN-, Vol. 01, No. 01, 2014).

Aziroh Nur, Mahmudatus Sa'diyah. Musyarakah Dalam Fiqih Dan Perbankan Syariah.(Equilibrium, Vol 02, No. 02, 2014).

Fatwa DSN No. 08/DSN-MUI/IV/2000 tentang pembiayaan Musyarakah Nisbah Journal, Vol. 01, No. 02: 76.

Nafan. (2014). Pembiayaan Musyarakah dan Mudharabah. Yogyakarta: Graha Ilmu.

Umam Khotibul. (2016) Perbankan Syariah: dasar-dasar dan dinamika perkembangannya. Jakarta: Rajawali.

Wangsawidjaja (2012) Pembiayaan Bank Syariah. Jakarta: PT Gramedia Pustaka Utama.

Widodo Sugeng. (2014) Moda Pembiayaan Lembaga Keuangan Islam Perspektif Alikatif. Yogyakarta: Kaukaba. 
Nur Huda, Fitri Fajri

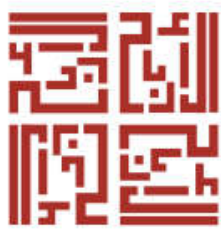

Yahya Riyal dkk. (2009) Akuntansi Perbankan Syariah Teori dan Praktik Kontemporer. Jakarta: Salemba Empat.

AL-ARBAH | 106 